\title{
Effects of Endoplasmic Reticulum Stress Inhibitor Treatment during the Micromanipulation of Somatic Cell Nuclear Transfer in Porcine Oocytes
}

\author{
Yeo-Reum Park ${ }^{1}$, Hye-Bin Park ${ }^{1}$, Mi-Jeong Kim ${ }^{1}$, Bae-Dong Jung ${ }^{1}$, Seunghyung Lee ${ }^{2}$, \\ Choon-Keun Park ${ }^{2}$, and Hee-Tae Cheong ${ }^{1}$ \\ ${ }^{1}$ College of Veterinary Medicine and Institute of Veterinary Science, Kangwon National University, Chuncheon 24341, Korea \\ ${ }^{2}$ College of Animal Life Sciences, Kangwon National University, Chuncheon 24341, Korea
}

\begin{abstract}
We examined the effects of endoplasmic reticulum (ER) stress inhibitor treatment during the micromanipulation of porcine somatic cell nuclear transfer (SCNT) on the in vitro development of SCNT embryos. ER stress inhibitors such as salubrinal $(200 \mathrm{nM})$ and tauroursodeoxycholic acid (TUDCA; $100 \mu \mathrm{M})$ were added to the micromanipulation medium and holding medium. The expression of X-box binding protein 1 (Xbpl), ER-stress-associated genes, and apoptotic genes in SCNT embryos was confirmed at the one-cell and blastocyst stages. Levels of Xbpl splicing and expression of ER-stressassociated genes in SCNT embryos at the one-cell stage decreased significantly with TUDCA treatment $(p<0.05)$. The expression of ER-stress-associated genes also decreased slightly with the addition of both salubrinal and TUDCA (Sal+TUD). The expression levels of caspase-3 and Bcl2-associated X protein (Bax) mRNA were also significantly lower in the TUDCA and Sal+TUD treatments $(p<0.05)$. At the blastocyst stage, there were no differences in levels of Xbp1 splicing, and transcription of ER-stress-associated genes and apoptosis genes between control and treatment groups. However, the blastocyst formation rate $(20.2 \%)$ and mean blastocyst cell number $(63.0 \pm 7.2)$ were significantly higher $(p<0.05)$ for embryos in the TUDCA treatment compared with those for control (12.6\% and $41.7 \pm 3.1$, respectively). These results indicate that the addition of ERstress inhibitors, especially TUDCA, during micromanipulation can inhibit cellular damage and enhance in vitro development of SCNT embryos by reducing stress levels in the ER.
\end{abstract}

Key words : Somatic cell nuclear transfer, Endoplasmic reticulum (ER) stress inhibitor, Micromanipulation, Apoptosis, Porcine

\section{INTRODUCTION}

Somatic cell nuclear transfer (SCNT) is a widely used technique with applications in diverse fields, such as animal cloning, biomedical research, and embryonic stem cell production. However, several problems can occur when this technique is used, such as abnormalities in the nuclear reprogramming of SCNT embryos or in offspring phenotypes, as a result of the in vitro environment (Hill et al.,
1999). Physical and chemical stresses generated during SCNT can lead to endoplasmic reticulum (ER) stress (Song et al., 2011; Lee et al., 2018), which in turn induces cellular damage, including apoptosis (Szegezdi et al., 2006; Tabas \& Ron, 2011; Lee et al., 2018) and mitochondrial dysfunction (Wu et al., 2015). Thus, ER stress is associated with low efficiency levels in SCNT procedures.

ER stress inhibitors are used to reduce ER stress and prevent ER-stress-induced apoptosis. Tauroursodeoxycholic

\footnotetext{
Manuscript received January 22, 2019, Received in revised form February 26, 2019, Accepted March 9, 2019

$\dagger$ Corresponding Author : Hee-Tae Cheong, College of Veterinary Medicine and Institute of Veterinary Science, Kangwon National University, Chuncheon 24341, Korea. Tel: +82-33-250-8659, E-mail: htcheong@kangwon.ac.kr
}

This is an Open Access article distributed under the terms of the Creative Commons Attribution Non-Commercial License (http:// creative-commons.org/licenses/by-nc/3.0) which permits unrestricted non-commercial use, distribution, and reproduction in any medium, provided the original work is properly cited. 
acid (TUDCA), a chemical chaperone derived from bile acid, is an ER stress inhibitor that has been used to stabilize ER protein folding and enhance ER function in a variety of cells and embryos (Xie et al., 2002; Ozcan et al., 2006; Zhang et al., 2012; Basar et al., 2014; Lin et al., 2016). Salubrinal, a eukaryotic initiation factor $2 \alpha$ (eIF2 $\alpha)$ dephosphorylating inhibitor, is also used as an ER stress inhibitor (Boyce et al., 2005). Salubrinal promotes the disassembly of the growth arrest and DNA damage-inducible protein 34 (GADD34)-protein phosphatase 1 (PP1) complex, and attenuates ER stress by maintaining eIF $2 \alpha$ phosphorylation. Salubrinal is reported to have low cytotoxicity (Boyce et al., 2005; Liu et al., 2012), but is rarely used for embryonic studies.

Embryonic studies using ER stress inhibitors have largely focused on the in vitro culture (IVC) stage for mitigating ER stress and cellular damage (Song et al., 2014). However, ER stress may occur before the IVC stage, such as during the micromanipulation process, and the resulting cellular damage could activate other stress signaling pathways (Lee et al., 2018). Thus, ER stress in SCNT embryos should be mitigated during the micromanipulation stage or immediately after the generation of ER stress instead of during the IVC stage. In this study, we examined the effects of ER stress inhibitor treatment during micromanipulation of porcine oocytes on ER stress, cellular damage, and in vitro development of SCNT embryos.

\section{MATERIALS AND METHODS}

\section{Chemicals}

All chemicals and reagents were purchased from SigmaAldrich Chemical Co. (St. Louis, MO, USA) unless otherwise indicated. Tunicamycin (TM), TUDCA (Merck, Darmstadt, Germany), and salubrinal were dissolved in dimethyl sulfoxide (Junsei Chemical, Tokyo, Japan) to prepare stock solutions that were then stored at $-20^{\circ} \mathrm{C}$ before use.

\section{Cell culture and chemical treatment}

Previously frozen and thawed porcine skin fibroblasts (pSFs) were seeded in 24-well plates (BD Sciences, San Diego, CA, USA) at a density of $2 \times 10^{4}$ cells $/ \mathrm{mL}$ for estimating the appropriate concentrations of the ER stress inhibitors. Cells were cultured in Dulbecco's modified Eagle's medium (DMEM; Gibco, Grand Island, NY, USA) supplemented with $10 \%$ fetal bovine serum (FBS; GenDEPOT, Katy, TX, USA) and 1\% (v/v) penicillin and streptomycin (P/S; Mediatech, Manassas, VA, USA) at $39^{\circ} \mathrm{C}$ and $5 \% \mathrm{CO}_{2}$ air concentration. The culture medium was replaced with fresh medium every 2 days. At $80 \%$ cell confluency, cells were cultured in the same medium with 2 $\mu \mathrm{g} / \mathrm{mL}$ of $\mathrm{TM}$, an ER stress inducer. We added various concentrations of salubrinal $(100,200$, or $400 \mathrm{nM})$ and TUDCA $(50,100$, or $200 \mu \mathrm{M})$ to two groups of TMtreated cells as well. All cells were then cultured for $3 \mathrm{hr}$. Non-treated cells served as the control. Cells were trypsinized and lysed in $30 \mu \mathrm{L}$ Lysis/Binding (L/B) buffer from the Dynabeads ${ }^{\circledR}$ mRNA Direct ${ }^{\mathrm{TM}}$ kit (Life Technologies, Oslo, Norway). The lysed cells were immediately stored at $-75^{\circ} \mathrm{C}$ for the analyses of ER stress and apoptosis.

\section{Isolation of oocytes and in vitro maturation}

Porcine ovaries were obtained from a local slaughterhouse and transported to the laboratory. Cumulus-oocyte complexes (COCs) were aspirated from antral follicles with a diameter of 3-6 mm using a $10-\mathrm{mL}$ syringe with an 18-gauge needle. COCs were washed in a Tyrode's lactate-4-(2-hydroxyethyl) piperazine-1-ethanesulfonic acid (TL-HEPES) buffer containing $0.1 \%$ (w/v) polyvinyl alcohol (PVA). COCs with homogeneous ooplasm and more than four layers of cumulus cells were selected and cultured in in vitro maturation (IVM) medium at $39^{\circ} \mathrm{C}$ and $5 \%$ $\mathrm{CO}_{2}$ air concentration for $42-44 \mathrm{hr}$. The IVM medium consisted of tissue culture medium 199 (TCM199; Gibco) supplemented with $0.1 \%$ (w/v) PVA, $3.05 \mathrm{mM}$ D-glucose, $0.91 \mathrm{mM}$ sodium pyruvate, $75 \mu \mathrm{g} / \mathrm{mL}$ penicillin $\mathrm{G}, 50 \mu \mathrm{g} / \mathrm{mL}$ 
streptomycin, $0.57 \mathrm{mM}$ cysteine, $10 \mathrm{ng} / \mathrm{mL}$ epidermal growth factor, $0.01 \mathrm{IU} / \mathrm{mL}$ luteinizing hormone, and 0.01 $\mathrm{IU} / \mathrm{mL}$ follicle stimulating hormone.

\section{Preparation of donor cells}

Using four-well dishes, pSFs were seeded and cultured with DMEM supplemented with $15 \%$ FBS and $1 \%(\mathrm{v} / \mathrm{v})$ $\mathrm{P} / \mathrm{S}$ at $39^{\circ} \mathrm{C}$ and $5 \% \mathrm{CO}_{2}$ air concentration for 6-7 days, until cells reached $100 \%$ confluency, to synchronize the cell cycle at the $G_{0} / G_{1}$ phase. The culture medium was replaced with fresh medium every 2 days. Cells were trypsinized with $0.05 \%(\mathrm{w} / \mathrm{v})$ trypsin-ethylenediaminetetraacetic acid (EDTA) and centrifuged $(500 \times \mathrm{g}, 5 \mathrm{~min}$, room temperature) in HEPES-buffered TCM199 supplemented with $0.78 \mathrm{mM}$ sodium bicarbonate, $0.14 \mathrm{mM}$ penicillin $\mathrm{G}$, $0.08 \mathrm{mM}$ streptomycin, and $3 \mathrm{mg} / \mathrm{mL}$ bovine serum albumin (BSA). Donor cells were placed in the same medium prior to SCNT.

\section{Nuclear transfer}

The cumulus cells of matured COCs were removed by vortexing for $3 \mathrm{~min}$ in phosphate-buffered saline (PBS; Gibco) supplemented with $0.1 \%$ (w/v) hyaluronidase and $0.1 \%$ (w/v) polyvinyl pyrolidone (PVP). SCNT was carried out in a micromanipulation medium of HEPES-buffered TCM-BSA containing $5 \mu \mathrm{g} / \mathrm{mL}$ cytochalasin B. Oocyte enucleation was conducted using an injection pipette by removing the first polar body and metaphase II chromosome mass together with a small amount of surrounding ooplasm. Then, a donor cell was injected into the perivitelline space of each enucleated oocyte. Each reconstructed oocyte was helded in a $50-\mu \mathrm{L}$ droplet of porcine zygote medium-3 (PZM-3; holding medium) until fusion treatment.

\section{Electrofusion and activation}

The reconstructed oocytes were manually aligned between two wire electrodes (1 mm apart) of a fusion chamber, and covered with a $0.3-\mathrm{M}$ mannitol solution contain- ing $0.1 \mathrm{mM}$ magnesium sulfate, $0.05 \mathrm{mM}$ calcium chloride, and 0.5 mM HEPES (Duchefa Biochemie, Haarlem, Netherlands). For electrofusion and activation, two pulses of direct current at $1.25 \mathrm{kV}$ were applied for $30 \mu \mathrm{sec}$ using the BTX Electro Cell Manipulator 200 (BTX, San Diego, CA, USA). After fusion and activation, reconstructed oocytes were incubated in holding medium at $39^{\circ} \mathrm{C}$ and $5 \%$ $\mathrm{CO}_{2}$ air concentration. Fusion state was checked $40 \mathrm{~min}$ after treatment.

\section{ER stress inhibitor treatment}

We investigated three ER stress inhibitor treatments. For the first two treatments, $200 \mathrm{nM}$ salubrinal or $100 \mu \mathrm{M}$ TUDCA was added to the micromanipulation medium and the holding medium. For the third treatment, both salubrinal and TUDCA (Sal+TUD) were added. After fusion and activation, reconstructed oocytes were incubated in PZM-3 with ER stress inhibitors for an additional $3 \mathrm{hr}$ at $39^{\circ} \mathrm{C}$ and $5 \% \mathrm{CO}_{2}$ air concentration before IVC.

\section{IVC and sampling}

Treatment and control SCNT embryos were cultured in fresh PZM-3 droplets for 6 days at $39^{\circ} \mathrm{C}$ and $5 \% \mathrm{CO}_{2}$ air concentration. Embryos were sampled at $20 \mathrm{hr}$ (one-cell stage) and day 6 (blastocyst stage) after fusion and activation, and washed in PBS containing 0.3\% (w/v) PVP. Washed embryos were lysed in $30 \mu \mathrm{L}$ of $\mathrm{L} / \mathrm{B}$ buffer, and stored immediately at $-75^{\circ} \mathrm{C}$ for the analyses of ER stress and apoptosis. Some blastocysts were stained with $2 \mu \mathrm{g} / \mathrm{mL}$ Hoechst 33342 for $30 \mathrm{~min}$. Stained embryos were mounted on a glass slide with VECTASHIELD (Vector Laboratories, Burlingame, CA, USA) under a cover slip, and cell numbers were counted using fluorescence microscopy (BX50; Olympus, Tokyo, Japan).

\section{RNA isolation and cDNA synthesis}

Total pSF RNA was extracted using TRIzol (Invitrogen, Carlsbad, CA, USA). The extracted RNA was precipitated 
using isopropyl alcohol (Junsei Chemical) and resolved with $10 \mu \mathrm{L}$ of diethyl pyrocarbonate-treated water (Biotech, Markham, Canada). The isolation of poly (A) mRNA from the SCNT embryos was conducted using a Dynabeads ${ }^{\circledast}$ mRNA Direct ${ }^{\mathrm{TM}}$ kit according to the manufacturer's protocol. Briefly, cryopreserved embryos were thawed and mixed with $30 \mu \mathrm{L}$ of Dynabeads ${ }^{\circledR}$ Oligo $(\mathrm{dT})_{25}$ by gentle shaking for $8 \mathrm{~min}$ at room temperature to allow the poly (A) mRNA tails to hybridize to the oligo (dT) ${ }_{25}$ on the beads. The beads with attached mRNA were first washed with $100 \mu \mathrm{L}$ of Washing Buffer A and then $100 \mu \mathrm{L}$ of Washing Buffer B. A DynaMag ${ }^{\mathrm{TM}}$-Spin Magnet (Invitrogen) was used to separate the beads from the supernatant. Poly(A) mRNA was eluted from the beads by incubation with $12.5 \mu \mathrm{L}$ of $10 \mathrm{mM}$ tris-hydrochloride buffer at $70^{\circ} \mathrm{C}$ for $5 \mathrm{~min}$, and the sample tube was then immediately placed on the magnet. The supernatant, which now contained the mRNA, was transferred to a $0.2-\mathrm{mL}$ microtube on ice. Total RNA and mRNA were reverse-transcribed into cDNA for subsequent analyses. cDNA synthesis was conducted using ReverTra Ace ${ }^{\circledR}$ qPCR RT Master Mix (Toyobo, Osaka, Japan) according to the manufacturer's protocol. Each template consisted of $6 \mu \mathrm{L}$ of total RNA or mRNA. The reaction was carried out in a Veriti ${ }^{\circledR}$ 96-well Thermal Cycler (Applied Biosystems, Foster City, CA, USA) at $65^{\circ} \mathrm{C}$ for $5 \mathrm{~min}, 4^{\circ} \mathrm{C}$ for $5 \mathrm{~min}, 37^{\circ} \mathrm{C}$ for $20 \mathrm{~min}$, $50^{\circ} \mathrm{C}$ for $5 \mathrm{~min}$, and $98^{\circ} \mathrm{C}$ for $5 \mathrm{~min}$. To eliminate genomic DNA, $2 \mu \mathrm{L}$ of $4 \times$ DN Master Mix was added to the reaction tube $5 \mathrm{~min}$ after the reaction start. Ten minutes later, 2 $\mu \mathrm{L}$ of $5 \times$ RT Master Mix II was added for the reverse transcription process. The cDNA products were stored at $4^{\circ} \mathrm{C}$.

\section{Reverse transcription-polymerase chain reac-} tion (RT-PCR) and real-time quantitative RT-PCR (RT-qPCR)

RT-PCR was used to detect levels of spliced X-box binding protein 1 (Xbpl), a key transcription factor associated with ER stress. Additionally, RT-qPCR was used to measure the expression of mRNAs from ER-stress-associated genes coding for $\mathrm{C} / \mathrm{EBP}$ homologous protein $(\mathrm{CHOP})$, binding protein $(B i P)$, activating transcription factor 4 (ATF4), and glucose-regulated protein 94 (GRP94), as well as apoptotic genes coding for $\mathrm{Bcl} 2$-associated $\mathrm{X}$ protein (Bax) and caspase-3. For the RT-PCR, cDNA samples were reverse-transcribed using AccuPower ${ }^{\circledR}$ Taq PCR PreMix (Bioneer, Daejeon, Korea) according to the manufacturer's instructions. The reaction consisted of an initial denaturation step of $1 \mathrm{~min}$ at $72^{\circ} \mathrm{C}$, followed by 34 amplification cycles of denaturation at $95^{\circ} \mathrm{C}$ for $30 \mathrm{sec}$, annealing at $58^{\circ} \mathrm{C}$ for $30 \mathrm{sec}$, and extension at $72^{\circ} \mathrm{C}$ for $50 \mathrm{sec}$. A final extension step of $5 \mathrm{~min}$ at $72^{\circ} \mathrm{C}$ was performed to complete the reaction. PCR products were examined with ultraviolet irradiation on a $4 \%$ agarose gel (Amresco, Cleveland, $\mathrm{OH}, \mathrm{USA}$ ) stained with $0.05 \%$ ethidium bromide (Bioneer). Band intensity was measured densitometrically using Gel Doc ${ }^{\mathrm{TM}} \mathrm{XR}+$ (Bio-Rad, Berkeley, CA, USA). RT-qPCR was conducted using Power SYBR Green PCR Master Mix (TOPreal ${ }^{\mathrm{TM}}$ qPCR 2X PreMIX, SYBR Green with high ROX; Enzynomics, Daejeon, Korea) in a StepOne Plus system (Applied Biosystems). The comparative CT $(\Delta \Delta \mathrm{CT})$ method (Livak \& Schmittgen, 2001) was used to measure the relative levels of mRNA expressed by each target gene. Glyceraldehyde 3-phosphate dehydrogenase (GAPDH) was used as an internal control to normalize target gene expression. The primer pairs synthesized for each gene are listed in Table 1.

\section{Statistical analysis}

At least three replicates were used for each statistical test. RT-PCR and RT-qPCR data were compared using analysis of variance and Duncan's multiple range test. Developmental rates were analyzed using the chi-square test, and blastocyst cell numbers were compared using Student's $t$-test. All analyses were conducted using the Statistical Analysis System software package (v.9.3; SAS Institute, Cary, NC, USA). 
Table 1. All primer sequences used for RT-PCR and RT-qPCR

\begin{tabular}{|c|c|c|c|c|}
\hline Genes & Primer sequences $\left(5^{\prime}-3{ }^{\prime}\right)$ & Length (bp) & GenBank acc. no. & Annealing temp. $\left({ }^{\circ} \mathrm{C}\right)$ \\
\hline $\mathrm{Xbp} 1$ & $\begin{array}{l}\text { F-GGCAGAGACCAAGGGGAATG } \\
\text { R-GGGTCGACTTCTGGGAGCTG }\end{array}$ & 263 & FJ213449.1 & 60 \\
\hline $\mathrm{CHOP}$ & $\begin{array}{l}\text { F-AAGACCCAGGAAACGGAAAC } \\
\text { R-TCCAGGAAAGGTCAGCAGTA }\end{array}$ & 261 & NM_001144845.1 & 58 \\
\hline $\mathrm{BiP}$ & $\begin{array}{l}\text { F-ACCAATGACCAAAATCGCCT } \\
\text { R-GTGACTTTCCAGCCACTCAA }\end{array}$ & 246 & J03214.1 & 58 \\
\hline ATF4 & $\begin{array}{l}\text { F-TGAGCCCTGACTCCTATCTG } \\
\text { R-TCCAGCTCTTTACATTCGCC }\end{array}$ & 277 & NM_001123078.1 & 58 \\
\hline GRP94 & $\begin{array}{l}\text { F-CTGCTGAAGGGGAAGTTACC } \\
\text { R-ATCATCTGAGTCCACAACGC }\end{array}$ & 197 & Y09136.1 & 58 \\
\hline Bax & $\begin{array}{l}\text { F-ACTGGACAGTAACATGGAGC } \\
\text { R-GTCCCAAAGTAGGAGAGGAG }\end{array}$ & 294 & XM003127290.3 & 55 \\
\hline Caspases-3 & $\begin{array}{l}\text { F-GAGGCAGACTTCTTGTATGC } \\
\text { R-CATGGACACAATACATGGAA }\end{array}$ & 237 & NM_214131 & 60 \\
\hline GAPDH & $\begin{array}{l}\text { F-GGGCATGAACCATGAGAAGT } \\
\text { R-AAGCAGGGATGATGTTCTGG }\end{array}$ & 230 & AF017079 & 58 \\
\hline
\end{tabular}

\section{RESULTS}

1. ER stress inhibitors mitigated TM-induced ER stress in somatic cells

Addition of TUDCA significantly reduced $(p<0.05)$ the levels of Xbpl splicing, which was induced by TM, in porcine fibroblasts in all TUDCA treatment groups (Fig. 1A). Expression levels of the ER-stress-associated genes (BiP, GRP94, ATF4, and CHOP) also decreased with addition of $100 \mu \mathrm{M}$ and $200 \mu \mathrm{M}$ TUDCA, but these differences were not significant (Fig. 1B). Expression levels of the ER-stressassociated genes were similar in the $100 \mu \mathrm{M}$ - and $200 \mu \mathrm{M}$ TUDCA treatments.

The effects of using $100 \mu \mathrm{M}$ and $200 \mu \mathrm{M}$ TUDCA on the in vitro development of porcine parthenogenetic em- bryos were examined in an additional experiment. As no differences in development were observed between treatments using the two TUDCA concentrations (unpublished data), $100 \mu \mathrm{M}$ TUDCA was used for the SCNT experiments.

The addition of both $200 \mathrm{nM}$ and $400 \mathrm{nM}$ salubrinal also significantly reduced $(\mathrm{p}<0.05)$ levels of TM-induced Xbpl splicing in porcine fibroblasts (Fig. 1C). Similarly, salubrinal resulted in down-regulation of ER-stress-associated genes. Overall, gene transcription levels were lower in treatments with $200 \mathrm{nM}$ and $400 \mathrm{nM}$ salubrinal compared to levels in the TM-only treatment (Fig. 1D). However, these decreases were not significantly different, except for BiP in the 200-nM salubrinal treatment (Fig. 1D).

The effects of using $200 \mathrm{nM}$ and $400 \mathrm{nM}$ salubrinal on the in vitro development of porcine parthenogenetic em- 

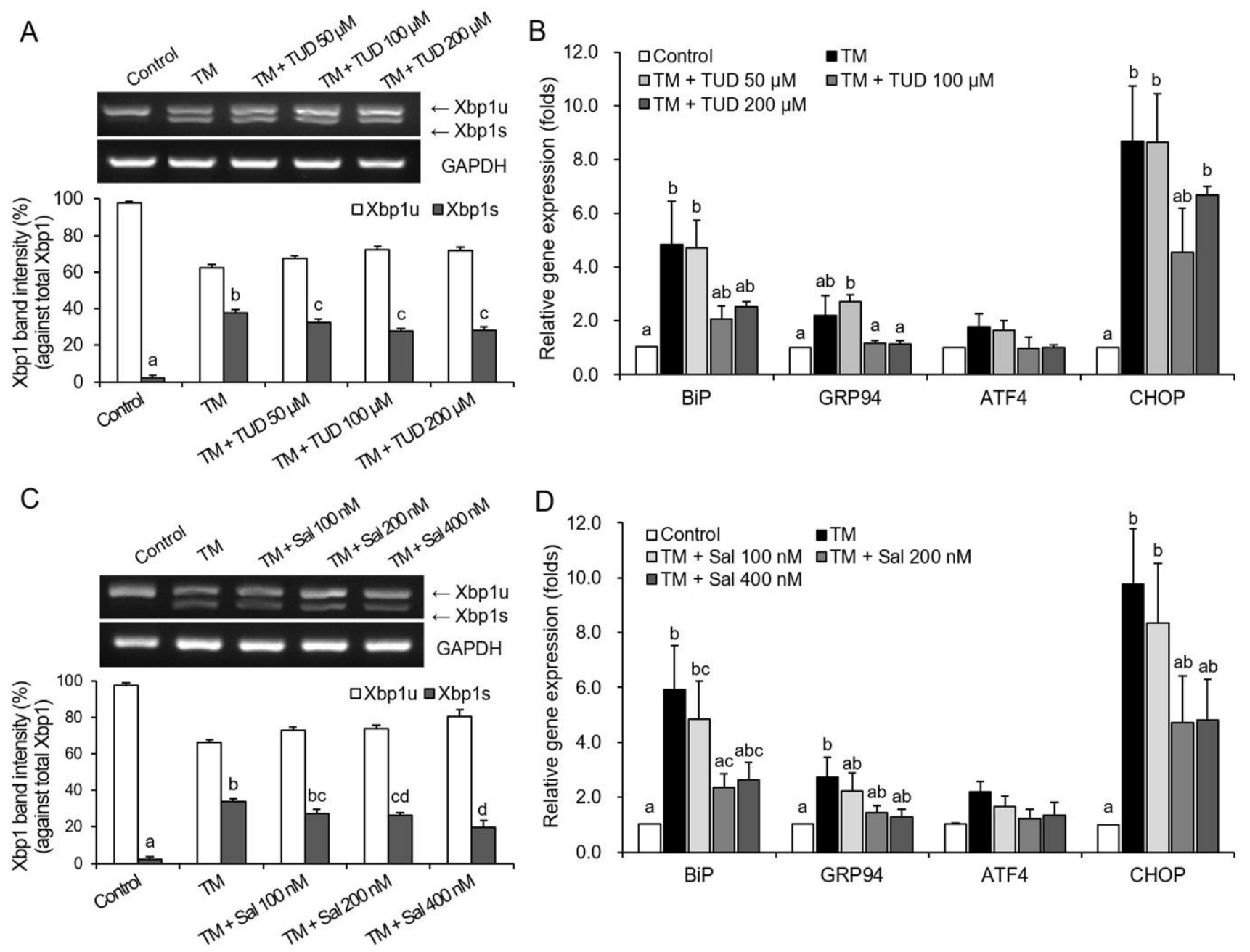

Fig. 1. Expression of $X b p 1$ mRNA and endoplasmic reticulum (ER) stress-associated genes in porcine somatic cells treated with tunicamycin (TM) and tauroursodeoxycholic acid (TUD), or TM and salubrinal (Sal). Cells were treated with $2 \mu \mathrm{g} / \mathrm{mL}$ TM and varying concentrations of TUD or Sal for $3 \mathrm{hr}$. The mRNAs of spliced (Xbpls) and unspliced (Xbplu) Xbpl were then detected using reverse transcription polymerase chain reaction (PCR). Band intensities for the (A) TM+TUD and (C) TM+Sal treatments were measured densitometrically, and expression levels of ER-stress-associated genes in the (B) TM+TUD and (D) TM+Sal treatments were measured using real-time quantitative PCR. Data are presented as mean \pm standard error. ${ }^{\text {add }}$ indicate significant differences at $p<0.05$.

bryos were also examined in an additional experiment. The results revealed that addition of $400 \mathrm{nM}$ salubrinal caused degeneration of parthenogenetic embryos (unpublished data). Thus, we used $200 \mathrm{nM}$ salubrinal for the SCNT experiments.

\section{Effects of ER stress inhibitors on ER stress and} apoptosis in SCNT embryos at the one-cell stage

At the one-cell stage, a significant decrease in Xbpl splicing levels in the SCNT embryos was observed only in the TUDCA treatment (Fig. 2A). The transcription levels of all ER-stress-associated genes decreased in all embryos treated with ER stress inhibitors, but transcription levels varied among genes (Fig. 2B). The transcription levels of GRP94, ATF4, and CHOP decreased significantly when SCNT embryos were treated with TUDCA $(p<0.05)$. In the Sal+TUD treatment, the transcription levels of $B i P$ and GRP94 were significantly lower $(p<0.05)$ than levels in the 


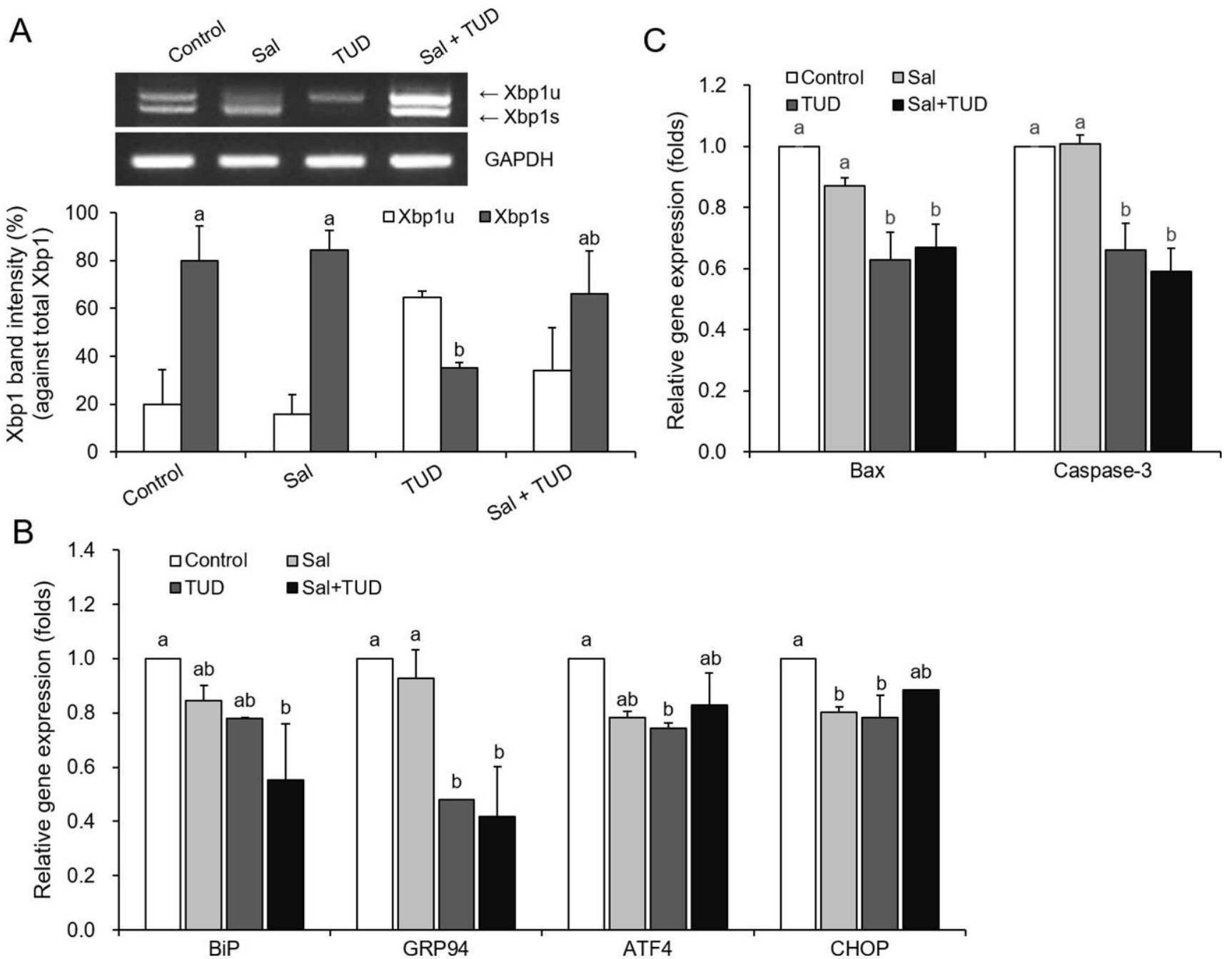

Fig. 2. Expression of Xbp1 mRNA, endoplasmic reticulum (ER) stress-associated genes, and apoptotic genes in somatic cell nuclear transfer (SCNT) embryos at the one-cell stage. Embryos were treated with $200 \mathrm{nM}$ salubrinal (Sal), $100 \mu \mathrm{M}$ tauroursodeoxycholic acid (TUD), or both Sal and TUD (Sal+TUD) during micromanipulation. SCNT embryos at the one-cell stage were sampled at $20 \mathrm{hr}$ after electrofusion. The mRNAs of spliced (Xbp1s) and unspliced (Xbp1u) Xbpl were then detected using reverse transcription polymerase chain reaction (PCR). (A) Band intensities from the reverse transcription PCR were measured densitometrically, whereas real-time quantitative PCR was used to quantify the expression of (B) ER-stress-associated genes and (C) apoptotic genes. Data are presented as mean \pm standard error. ${ }^{\mathrm{a}, \mathrm{b}}$ indicate significant differences at $p<0.05$.

control, and in the salubrinal treatment only $C H O P$ had a significantly lower transcription level $(p<0.05)$ than control levels.

During micromanipulation, addition of salubrinal did not reduce apoptosis rates in the SCNT embryos at the one-cell stage. However, transcription levels of Bax and caspase-3 mRNAs were significantly lower $(p<0.05)$ in the TUDCA and
Sal+TUD treatments compared with control levels (Fig. 2C).

\section{Effects of ER stress inhibitors on ER stress and} apoptosis in SCNT embryos at the blastocyst stage

No significant differences were observed for levels of Xbpl splicing or ER-stress-associated gene expression among all treatments and the control in SCNT embryos at 
the blastocyst stage (Fig. 3A, B), and no significant differences in the transcription levels of the Bax and caspase-3 apoptotic genes were observed among groups (Fig. 3C).

\section{Effects of ER stress inhibitors on in vitro devel-} opment of SCNT embryos

No differences in cleavage rate $(69.2 \%-73.9 \%)$ were observed between control and treatment groups. Blastocyst formation rates and mean blastocyst cell numbers in the salubrinal (15.4\% and 53.7 \pm 4.5 , respectively) and $\mathrm{Sal+}$ TUD (12.2\% and 54.0 \pm 3.0 , respectively) treatments did not differ significantly from those of control embryos (12.6\% and 41.7 \pm 3.1 , respectively). However, blastocyst development (20.2\%) and mean blastocyst cell number $(63.0 \pm 7.2)$ were significantly higher $(p<0.05)$ in embryos treated with TUDCA than in control embryos (Table 2).
A
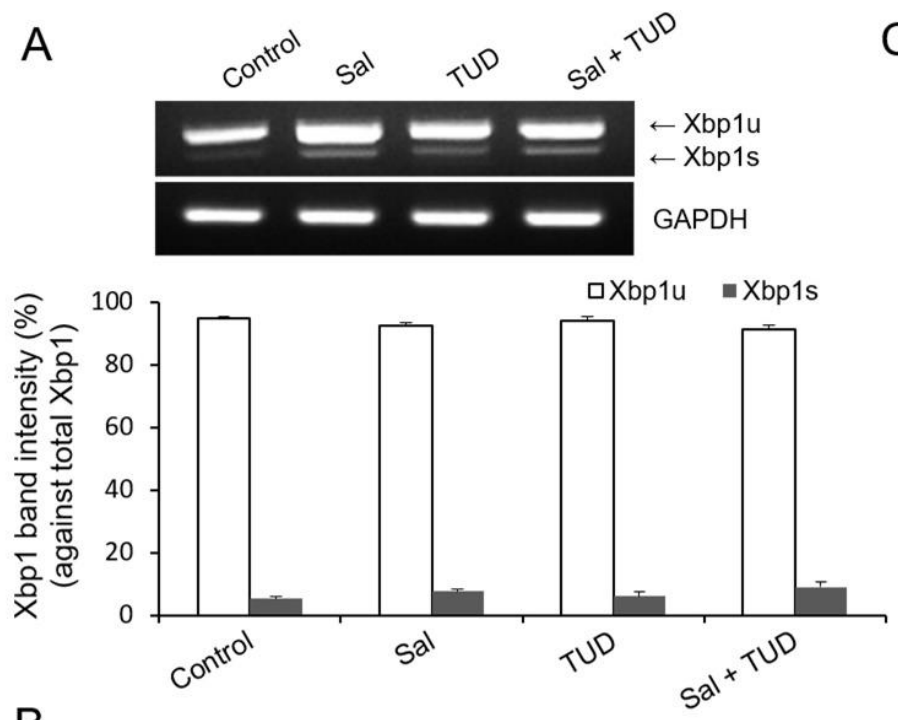

C

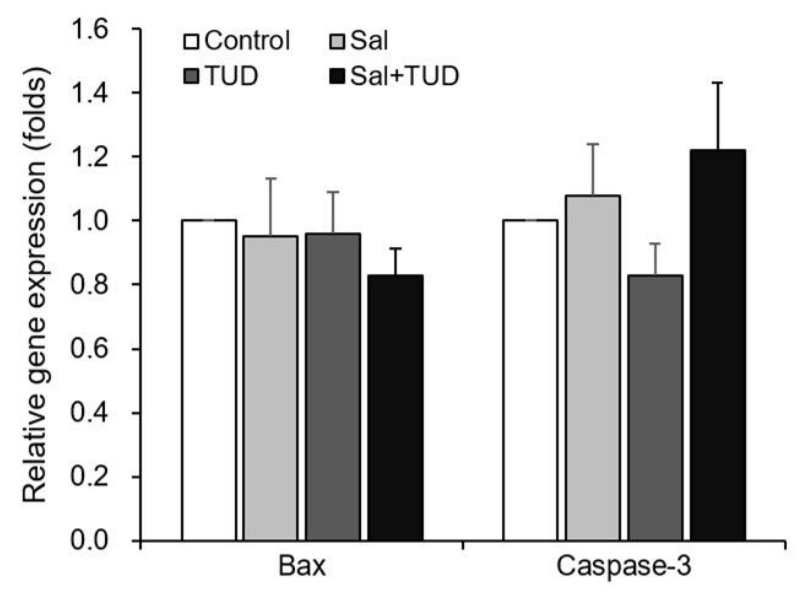

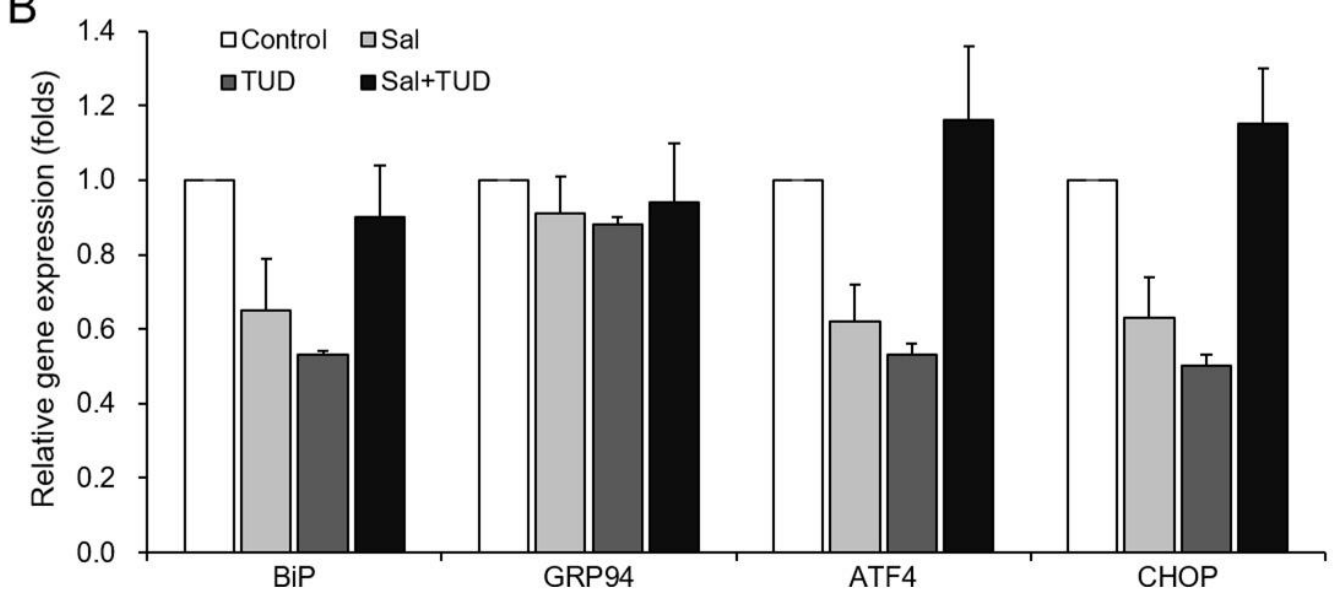

Fig. 3. Expression of $X b p 1 \mathrm{mRNA}$, endoplasmic reticulum (ER) stress-associated genes, and apoptotic gene in somatic cell nuclear transfer (SCNT) embryos at the blastocyst stage. Embryos were treated with $200 \mathrm{nM}$ salubrinal (Sal), $100 \mu \mathrm{M}$ tauroursodeoxycholic acid (TUD), or both Sal and TUD (Sal+TUD) during micromanipulation, and then cultured for 6 days. The mRNAs of spliced $(X b p 1 s)$ and unspliced $(X b p 1 u) X b p 1$ were then detected using reverse transcription polymerase chain reaction (PCR). (A) Band intensities from the reverse transcription PCR were measured densitometrically, whereas real-time quantitative PCR was used to quantify the expression of (B) ERstress-associated genes and (C) apoptotic genes. Data are presented as mean \pm standard error. 
ER Stress Inhibitor Effect during Porcine SCNT

Table 2. Effect of endoplasmic reticulum stress inhibitor treatment during micromanipulation on the in vitro development of somatic cell nuclear transfer embryos

\begin{tabular}{ccccc}
\hline \hline \multirow{2}{*}{ Treatment } & $\begin{array}{c}\text { No. of embryos } \\
\text { cultured }\end{array}$ & \multicolumn{2}{c}{ No. of embryos developed to } & \multirow{2}{*}{$\begin{array}{c}\text { Cell no. in blastocysts } \\
\text { (mean } \pm \text { S.E) }\end{array}$} \\
\cline { 3 - 4 } Control & 182 & $126(69.2)$ & $23(12.6)^{\mathrm{a}}$ & $41.7 \pm 3.1^{\mathrm{a}}$ \\
Sal & 208 & $147(70.7)$ & $32(15.4)^{\mathrm{ab}}$ & $53.7 \pm 4.5^{\mathrm{ab}}$ \\
TUD & 203 & $150(73.9)$ & $41(20.2)^{\mathrm{b}}$ & $63.0 \pm 7.2^{\mathrm{b}}$ \\
Sal+TUD & 197 & $140(71.1)$ & $24(12.2)^{\mathrm{a}}$ & $54.0 \pm 3.0^{\mathrm{ab}}$ \\
\hline
\end{tabular}

Experiments were repeated 6 times in each treatment group.

${ }^{\mathrm{a}, \mathrm{b}}$ Values with different letters are significantly different $(p<0.05)$.

Sal, salubrinal; TUD, tauroursodeoxycholic acid (TUDCA).

\section{DISCUSSION}

In the in vitro environment, stimuli from experimental processes can cause ER stress in embryos. Both electric stimuli and the calcium $\left(\mathrm{Ca}^{2+}\right)$ ionophore (A23187), which are commonly used in SCNT, have been reported to disturb $\mathrm{Ca}^{2+}$ homeostasis of the ER and induce ER stress (Brostrom et al., 1995; Fernandez et al., 1996). Our previous study revealed that A23187-mediated activation increased levels of ER stress and apoptosis in porcine parthenogenetic embryos (Park et al., 2017). In a related study, expression levels of ER-stress-associated genes were reported to be higher in SCNT embryos than in in vitro fertilized (IVF) embryos, suggesting that ER stress and ERstress-induced apoptosis may occur during SCNT (Lee et al., 2018). Micromanipulation has also been reported to generate excessive amounts of reactive oxygen species (ROS) in SCNT embryos (Hwang et al., 2013), and ROS is a trigger of ER stress (Malhotra et al., 2008).

The results from our study indicate that addition of ER stress inhibitors during micromanipulation can reduce ER stress and subsequent embryonic cell damage. However, compared to TUDCA, the addition of salubrinal or both salubrinal and TUDCA (Sal+TUD treatment) did not re- duce the levels of $\mathrm{Xbpl}$ splicing or expression of several ER-stress-associated genes. Although combining both salubrinal and TUDCA led to reduced expression of BiP and GRP94, the expression of ATF4 and CHOP increased relative to treatments in which each inhibitor was used individually (see Fig. 2B). No significant differences in gene expression were observed among all groups at the blastocyst stage. This may have been because the effects of the ER stress inhibitors diminished during the 6 days of IVC. The embryos developed to the blastocyst stage would have already overcome the ER stress induced by micromanipulation, so that there were no differences in levels of $\mathrm{Xbpl}$ splicing and expression of ER-stress-associated genes between treatment and control groups.

In the treatment using $100 \mu \mathrm{M}$ TUDCA, inhibition of ER stress during micromanipulation, but not while culturing, resulted in better outcomes of in vitro development at the blastocyst stage, similar to results reported in other studies. Addition of $100 \mu \mathrm{M}$ TUDCA during the IVC of porcine SCNT embryos significantly increased blastocyst formation, cell numbers of the inner cell mass, and total blastocyst cell numbers compared to levels in control embryos (Lin et al., 2016). TUDCA has also been reported to inhibit ER stress and ER-stress-induced apoptosis in 
porcine parthenogenetic embryos, and promote maturation of COCs and embryonic development (Zhang et al., 2012b). Similarly, Song et al. (2011) reported that addition of TUDCA reduced levels of Xbpl splicing, transcription of the ER-stress-associated gene GRP78, which codes for ATF6, an $\alpha$-mannidose-like protein that enhances ER degradation, and blastomere apoptosis in bovine SCNT embryos. In addition, TUDCA can reduce hyperosmolar-induced ER stress and ER-stress-induced apoptosis during oocyte development, and promote embryonic development in mouse embryos (Zhang et al., 2012a; Basar et al., 2014; Mochizuki et al., 2018). In contrast to previous studies, we applied TUDCA only during micromanipulation and $3 \mathrm{~h}$ after fusion and activation, not during the IVC stage, to enhance the in vitro development of the SCNT embryos. Our results reveal that immediate suppression of ER stress during micromanipulation can enhance development in SCNT embryos by increasing blastocyst cell numbers. Thus, ER stress has to be inhibited or removed during micromanipulation for optimal reprogramming of SCNT embryos.

Although it is also an ER stress inhibitor, addition of salubrinal did not enhance embryonic development in our study, implying that salubrinal is not as effective as TUDCA. However, addition of $100 \mathrm{nM}$ and $200 \mathrm{nM}$ salubrinal to mouse COCs during IVM was reported to mitigate the deficiencies induced by ER stress, including lowered levels of protein secretion and mitochondrial activity, and lowered developmental capacity of IVF embryos (Wu et al., 2012). Addition of $400 \mathrm{nM}$ salubrinal during IVM has also been shown to promote in vitro development of bovine IVF embryos and reduce ER stress markers (SuttonMcDowall et al., 2016). Inconsistencies between these results and our findings are likely due to the different species used for experiments and differences in treatment conditions. Additionally, different ER stress factors are involved during SCNT and IVM, which may have differ- ent effects on the activation of the protein kinase RNA-like endoplasmic reticulum kinase (PERK) signaling pathway and the inhibitory function of salubrinal, an $e I F 2 \alpha$-specific ER stress inhibitor.

IRE 1 $\alpha$, PERK, and ATF6 are all sensors of the unfolded protein response (UPR), but have different sensitivities depending on the cause of ER stress. For example, PERK responds rapidly to ER stress caused by disturbance of $\mathrm{Ca}^{2+}$ concentrations in the ER lumen, but does not respond to ER stress caused by reducing agents (Hetz et al., 2012).

Although apoptotic gene expression decreased in embryos treated with TUDCA, addition of both salubrinal and TUDCA did not enhance embryonic development in our study. This may have been due to increased expression of ATF4 and CHOP at the one-cell stage. Because $C H O P$ is an important mediator of apoptosis induced by ER stress (Zinszner et al., 1998), CHOP-mediated apoptotic pathways may still have affected embryonic development in the Sal+TUD treatment, despite the reduced expression of Bax and caspase-3. Furthermore, levels of Xbpl splicing decreased in embryos treated with TUDCA, but not in the other embryos. This implies that Xbpl splicing in the early SCNT embryo is important for in vitro development. Zhang et al. (2012a) reported that peak Xbpl expression occurred at the four-cell stage, which is the same stage of genomic activation. This implies that Xbpl may be associated with embryonic development in pigs.

In conclusion, our results reveal that addition of ER stress inhibitors, particularly TUDCA, during micromanipulation reduces ER stress levels in early porcine SCNT embryos, and increases embryonic developmental potential in vitro by preventing apoptosis. Further studies are needed to clarify the relationship between UPR signaling and SCNT embryonic reprogramming.

\section{ACKNOWLEDGEMENTS}

This study was supported by Basic Science Research 
Program through the National Research Foundation of Korea (NRF) funded by the Ministry of Education (2016R1D1 A1B03930662).

\section{REFERENCES}

Basar M, Bozkurt I, Guzeloglu-Kayisli O, Sozen B, Tekmen I, Schatz F, Arici A, Lockwood CJ, Kayisli UA (2014) Unfolded protein response prevents blastocyst formation during preimplantation embryo development in vitro. Fertil Steril 102:1777-1784.

Boyce M, Bryant KF, Jousse C, Long K, Harding HP, Scheuner D, Kaufman RJ, Ma D, Coen DM, Ron D, Yuan J (2005) A selective inhibitor of eIF2alpha dephosphorylation protects cells from ER stress. Science 307:935-939.

Brostrom MA, Prostko CR, Gmitter D, Brostrom CO (1995) Independent signaling of grp78 gene transcription and phosphorylation of eukaryotic initiator factor 2 alpha by the stressed endoplasmic reticulum. J Biol Chem 270:4127-4132.

Fernandez F, Jannatipour M, Hellman U, Rokeach LA, Parodi AJ (1996) A new stress protein: Synthesis of Schizosaccharomyces pombe UDP-Glc:glycoprotein glucosyltransferase mRNA is induced by stress conditions but the enzyme is not essential for cell viability. EMBO J 15:705-713.

Hetz C (2012) The unfolded protein response: Controlling cell fate decisions under ER stress and beyond. Nat Rev Mol Cell Biol 13:89-102.

Hill JR, Roussel AJ, Cibelli JB, Edwards JF, Hooper NL, Miller MW, Thompson JA, Looney CR, Westhusin ME, Robl JM, Stice SL (1999) Clinical and pathologic features of cloned transgenic calves and fetuses (13 case studies). Theriogenology 51:1451-1465.

Hwang IS, Bae HK, Cheong HT (2013) Mitochondrial and DNA damage in bovine somatic cell nuclear transfer embryos. J Vet Sci 14:235-240.

Lee HY, Bae HK, Jung BD, Lee S, Park CK, Yang BK,
Cheong HT (2018) Analysis of endoplasmic reticulum (ER) stress induced during somatic cell nuclear transfer (SCNT) process in porcine SCNT embryos. Dev Reprod 22:73-83.

Lin T, Lee JE, Oqani RK, Kim SY, Cho ES, Jeong YD, Baek JJ, Jin DI (2016) Tauroursodeoxycholic acid improves pre-implantation development of porcine SCNT embryo by endoplasmic reticulum stress inhibition. Reprod Biol 16:269-278.

Liu CL, Li X, Hu GL, Li RJ, He YY, Zhong W, Li S, He KL, Wang LL (2012) Salubrinal protects against tunicamycin and hypoxia induced cardiomyocyte apoptosis via the PERK-eIF2 $\alpha$ signaling pathway. J Geriatr Cardiol 9:258-268.

Livak KJ, Schmittgen TD (2001) Analysis of relative gene expression data using real-time quantitative PCR and the 2(-Delta Delta C(T)) method. Methods 25:402-408.

Malhotra JD, Miao H, Zhang K, Wolfson A, Pennathur S, Pipe SW, Kaufman RJ (2008) Antioxidants reduce endoplasmic reticulum stress and improve protein secretion. Proc Nat Acad Sci USA 105:18525-18530.

Mochizuki M, Miyagi K, Kishigami S (2018) Optimizing treatment of tauroursodeoxycholic acid to improve embryonic development after in vitro maturation of cumulus-free oocytes in mice. PLOS ONE 13:e0202962.

Ozcan U, Yilmaz E, Ozcan L, Furuhashi M, Vaillancourt E, Smith RO, Gorgun CZ, Hotamisligil GS (2006) Chemical chaperones reduce ER stress and restore glucose homeostasis in a mouse model of type 2 diabetes. Science 313:1137-1140.

Park HB, Park YR, Lee HY, Bae HK, Lee SH, Park CK, Yang BK, Cheong HT (2017) Endoplasmic reticulum (ER) stress and apoptosis in parthenogenetic porcine embryos following different combination of activation methods. J Emb Trans 32:25-31.

Song BS, Kim JS, Yoon SB, Lee KS, Koo DB, Lee DS, Choo YK, Huh JW, Lee SR, Kim SU, Kim SH, Kim HM, Chang KT (2011) Inactivated Sendai-virus-me- 
diated fusion improves early development of cloned bovine embryos by avoiding endoplasmic-reticulumstress-associated apoptosis. Reprod Fertil Dev 23:826836.

Song BS, Yoon SB, Sim BW, Kim YH, Cha JJ, Choi SA, Jeong KJ, Kim JS, Huh JW, Lee SR, Kim SH, Kim SU, Chang KT (2014) Valproic acid enhances early development of bovine somatic cell nuclear transfer embryos by alleviating endoplasmic reticulum stress. Reprod Fertil Dev 26:432-440.

Sutton-McDowall ML, Wu LL, Purdey M, Abell AD, Goldys EM, MacMillan KL, Thompson JG, Robker RL (2016) Nonesterified fatty acid-induced endoplasmic reticulum stress in cattle cumulus oocyte complexes alters cell metabolism and developmental competence. Biol Reprod 94:23, 1-9.

Szegezdi E, Logue SE, Gorman AM, Samali A (2006) Mediators of endoplasmic reticulum stress-induced apoptosis. EMBO Ret 7:880-885.

Tabas I, Ron D (2011) Integrating the mechanisms of apoptosis induced by endoplasmic reticulum stress. Nat Cell Biol 13:184-190.

Wu LL, Russell DL, Norman RJ, Robker RL (2012) Endoplasmic reticulum (ER) stress in cumulus-oocyte complexes impairs pentraxin-3 secretion, mitochondrial mem- brane potential $(\Delta \Psi \mathrm{m})$, and embryo development. Mol Endocrinol 26:562-573.

Wu LL, Russell DL, Wong SL, Chen M, Tsai T, St John JC, Norman RJ, Febbraio MA, Carroll J, Robker RL (2015) Mitochondrial dysfunction in oocytes of obese mothers: Transmission to offspring and reversal by pharmacological endoplasmic reticulum stress inhibitors. Development 142:681-691.

Xie Q, Khaoustov VI, Chung CC, Sohn J, Krishnan B, Lewis DE, Yoffe B (2002) Effect of tauroursodeoxycholic acid on endoplasmic reticulum stress-induced caspase-12 activation. Hepatology 36:592-601.

Zhang JY, Diao YF, Kim HR, Jin DI (2012a) Inhibition of endoplasmic reticulum stress improves mouse embryo development. PLOS ONE 7:e40433.

Zhang JY, Diao YF, Oqani RK, Han RX, Jin DI (2012b) Effect of endoplasmic reticulum stress on porcine oocyte maturation and parthenogenetic embryonic development in vitro. Biol Reprod 86:128, 1-9.

Zinszner H, Kuroda M, Wang X, Batchvarova N, Lightfoot RT, Remotti H, Stevens JL, Ron D (1998) CHOP is implicated in programmed cell death in response to impaired function of the endoplasmic reticulum. Genes Dev 12:982-995. 